DOI https://doi.org/10.30525/978-9934-26-026-1-13

\title{
NARRATIVIZATION OF FEAR IN DIGITAL PRACTICES OF POLITICAL MANIPULATION
}

\author{
Uhryn L. Ya., Sviderska O. I., Bula S. P.
}

\section{INTRODUCTION}

The development of contemporary societies is based predominantly on the growing influence of qualitatively new factors and determinants, intangible in nature. The production of knowledge, information and symbols in the post-industrial and globalized society resulted in the emergence of artificially created multiple images of reality (Baudrillard simulacra), through which individuals perceive most processes and events. Alongside with the development of information technology and new media, this lays the groundwork for the application of manipulative practices by various actors, even outside the influence of state institutions. The fundamental of manipulative practices, which since ancient times from generation to generation were "honed" and employed by leaders and political forces in systems of domination, was the impact on people's emotions, the management of the emotional sphere of society. At the present stage, these practices are transformed into systemic technologies of social management, "brainwashing", construction of needs and ideas. Back in the 50s of the twentieth century Walter Lippmann stated that political theory should pay more attention to the issues that arose due to the fact that "pictures in people's minds are not a mechanical reflection of the world around them"1. In the current context, the massive influence of manipulative practices constantly increases the mismatch of these pictures to the point of substituting the objective reality, constructed by politicians and the media. The new reality can be contradictory, confusing, ambivalent, or represent, as defined by Ruth Wodak, "a deceptively simple illusion in contrast to the very real complexity and pluralism of modern societies" 2 .

The above-mentioned transformations problematize the study of the manipulative potential of emotional factors, especially in the context of the global coronavirus pandemic, when the lives of most people are extremely destabilized, the future is uncertain, and the information is contradictory.

\footnotetext{
1 Липпман У. Общественное мнение / Пер. с англ. Москва : Институт Фонда «Общественное мнение», 2004. С. 51.

${ }^{2}$ Водак Р. Политика страха. Что значит дискурс правых популистов? / Пер. с англ. Кочергина Е.Н., Гритчина В.В. Харьков : Изд-во «Гуманитарный центр», 2018. C. 46 .
} 
In this situation, the use of fear as an emotional response to objective (coronavirus) and imaginary, discursively and media-generated threats, allows us to talk about the conscious application of the policy and culture of fear by the actors who make decisions at different levels - from local to global.

Digitalization of politics, new social media and the constant development of Internet technologies contribute to the application of fear in sales, grants, election campaigns, astroturfing operations, constructing political threats, concealing the true decision-making motives of actors, and so on. Fear manifested by relevant discourses and narratives can notably affect the formation of new values, ideologies, changes in the principles of international cooperation.

It should be emphasized that the culture of fear discussed in this section is not a new concept, as, indeed, the narrative of fear; however, in the context of the socio-political changes taking place at the present stage, their study is relevant to the social sciences. Despite the considerable amount of research, the new realities of the global pandemic formulate new challenges and issues that require thorough analysis. In particular, more research needs to be done in relation to the perception of fear narratives reinforced by the development of the new media, by the practical helplessness of institutions, their inability to control online violence, by the globalization of digital policy, and, ultimately, the use of mechanisms to spread the culture of fear by government officials themselves. The bases of our analysis were the principles of postmodernism, social constructivism, elements of discourse analysis.

\section{Fear as a means of manipulation in political practices}

Manipulation of the mass consciousness, along with the violence, has long been a common means to achieve political objectives, which would be impossible without changing, transforming or forming of new attitudes, beliefs, values and, consequently, behaviour. However, if in the remote past the principal means of manipulation were the gift of oratory, religious symbols and rituals, nowadays the mechanisms of manipulative influence have changed significantly owing to technology; nonetheless the targets themselves remain the same. To achieve their goal, the manipulators are able to use a whole army of stakeholders who purposefully engage in the "profiling" of modern individuals through the study and construction of their needs, in particular by analysing profiles on social networks. In the psychological manipulation, the term "target" refers to a mental structure which is influenced, regardless of the manipulator's awareness and intention. Normally, the major "targets" of manipulation are needs, motives, attitudes, values, emotions, etc. Accordingly, the separate segment of political 
manipulation at the present stage is the skilful selection of "keys" to the emotional sphere of the individual, i.e. micro-targeting, since it is the emotions that mediate the understanding of needs, motives and patterns of behaviour. Emotions have always been important: religious, national, ideological, even exceptionally personal ${ }^{3}$. On the one hand, as P. Ekman rightly points out, under the influence of emotions an individual can perform actions that seem to be logically relevant, on the other hand, under the impact of a certain emotional strain we are capable to take actions of which we may be ashamed in the future ${ }^{4}$. As a result, although emotions can save lives, they can cause serious harm. D. Gardner explains this by the two systems of thinking, which developed in humans in the process of evolution. One of them is Feelings, the other is Mind. The first system, which was formed throughout human history, is guided by simple "universal rules", by "automatic settings" that "allow it to assess the situation almost instantly". Simultaneously, these "universal rules", which we apply instinctively, can lead to "irrational conclusions", mistakenly "activating the alarm"5. The effect can be anxiety, fear, and even panic for which there is no objective reason. This false emotional mechanism can be triggered consciously.

In the psychological dictionary edited by V. Davydov, a fairly broad definition of emotion can be found. "Emotions" are a special class of mental processes and states connected with instincts, needs and motives, which are manifested in the form of direct experience (pleasure, joy, fear, etc.) of important and affecting the individual phenomena and situations for the realization of life activities ${ }^{6}$. On the basis of this definition, we will make some fundamental clarifications that distinguish emotions from other mental processes: 1) they are characterized by fugacity and intensity of running (fear, anger, joy, horror); 2) in accordance with the mechanisms of the dominant (including the mechanism of suppression of other stimuli) emotions disrupt behaviour. Only after the arousal associated with their manifestations, the organism returns to the state of equilibrium. In other words, emotions first motivate activity and then fade away; 3 ) emotions are manifested only in specific circumstances; 4) emotions have personal significance and are situational in nature; 5) emotions can arise as a result of

3 Муазі Д. Геополітика емоцій. Як культури страху, приниження та надії змінюють світ / Пер. $з$ англ. О. Гординчук. Київ : Брайт Стар паблішинг, 2018. С. 20.

4 Экман П. Психология эмоций. Я знаю, что ты чувствуешь. 2-е изд. / Пер. с англ. Санкт-Петербург : Питер, 2010. С. 10.

${ }^{5}$ Гарднер Дэн. Страх. Почему мы неправильно оцениваем риски, живя в самое безопасное время в истории / пер. с англ. Ю. Константинова. Москва : ООО «Манн, Иванов и Фербер», 2019. С. 24-25.

${ }^{6}$ Давыдов В.В. Психология деятельности как основа формирования способности и готовности к практической деятельности. Москва : Наука, 1997. С. 54. 
both external causes and circumstances, and internal states of the organism, thoughts. Feelings, as defined by D. Gardner, are a source of "instantaneous judgments that we take for intuition or emotion, such as insecurity, anxiety, fear. The decision made under the pressure of the Feelings is almost impossible to put into words. It is impossible to explain why you feel one way or another, you just know it" ${ }^{\prime 7}$. So, emotions are usually a prompt and not always rational reaction to stimuli. Therefore, the emotions, which are actualized in almost all spheres of human life, are under the manipulative influence of modern marketing experts, which affords an opportunity to draw attention to products, brands, politicians or parties.

The manipulative technologies pay the most attention to negative emotions - envy, hatred, narcissism, anger, etc., which have the highest level of arousal and are difficult to control the consciousness of the individual. The sensual, according to S. Kara-Murza, is always closer to the outside world than, for example, thinking, so its reaction is always faster and mostly directed by rational reasoning ${ }^{8}$. This turns emotions into an effective resource that is the easiest to exploit for manipulative purposes. Manipulators are primarily interested in instinctive or aggressive reactions to certain triggers: sex, feelings of ownership, hostility to people who are different from us, resistance to the temptation of power, fame, luxury, and so on $^{9}$. Hence, in manipulative technologies, actors exploit those instinctive reactions that work automatically: the need for security, food, a sense of social belonging, etc. The logic of manipulators is obvious: the wider the audience to be influenced, the more universal the "targets" have to be. Specialization and accuracy of the direction of influence is possible when the specific characteristics of the audience as an object of manipulation are known; accordingly, the smaller the group of people is, the more accurate the impact should be. When such adjustment of targeting for some reason does not occur, E. Dotsenko believes that the "targets" of manipulation remain standard: pride, desire for pleasure, comfort, family comfort, sense of status, popularity ${ }^{10}$.Yet this approach may not work, because any manipulative actions involve the initial collection of information about the emotional and sensual world of the target audience, their attitudes, stereotypes, desires, emotional state, values, including political ones, as well as the pre-construction of "necessary" attitudes and emotions. An example is

${ }^{7}$ Гарднер Д. Страх. Почему мы неправильно оцениваем риски, живя в самое безопасное время в истории / Пер. с англ. Ю. Константинова. Москва : ООО «Манн, Иванов и Фербер», 2019. С. 25.

${ }^{8}$ Кара-Мурза С. Манипуляция сознанием. Москва : Эксмо, 2005. 145 с.

9 Доценко Е.Л. Психология манипуляции: феномены, механизмы и защита. Москва : ЧеРо, Издательство МГУ, 1997. С. 110.

${ }^{10}$ Там само. С. 115. 
the creation of the myth of the president as a "father of the nation" or a "servant of the people", a "saviour", while the target audience is characterized by predominantly paternalistic attitudes and a sense of danger. Manipulative technologies also use the natural feelings of pity and compassion for the weak. As paradoxical as it may seem, the constructed image of a politician who is weak, offended and persecuted, which should signal the inability or even unwillingness to govern, in certain societies (in Ukrainian, in particular) is positively perceived by the mass consciousness.

The emotional and sensual sphere is the environment where, due to chain reaction and emotional contagion, messages spread quickly, the result of which is the formation of the desired mood, thoughts or beliefs and behaviours. However, in this process, as highlighted by S. Kara-Murza, there is no individual ${ }^{11}$. The processes of internalization and imitation ensure the rapid and massive spread of emotions and feelings. There is an abundance of examples of such psychological contagion throughout the history. For instance, the medieval psycho-epidemics of self-flagellation, the dance in Italy, the epidemic of convulsionists in France, the mania of tulips in Holland; there are known epidemics of mass feelings in modern societies as exemplified by numerous flash mobs and infoviruses.

Actually, the modern globalized world is "an ideal fertile ground for the flourish or even explosion of emotions" due to the feelings of insecurity and loss of self-determination (identity). "Self-determination is strongly related to confidence, which in turn (or the lack thereof) is expressed in emotions and especially in fear, hope and humiliation" ${ }^{\prime 2}$. This thesis is also emphasized by Zygmunt Bauman: modern fears and experiences cause individuals to lose their sense of community, they have to "suffer in solitude" 13 . The crisis of state institutions, their inability to meet the vital needs of the individual, including the need for security, strengthens the emotional background of modern societies. Of greatest concern is the lack of clear rules of the game, non-compliance with the law and permissiveness, despite the need of individuals to be protected by the functioning justice system.

The emotions of the globalized society, which are fuelled by the media, cinema, mass culture and especially the new social media, have become an influential factor in modern political processes that are aimed primarily at radical and possibly anti-systemic changes in societies and international

${ }^{11}$ Кара-Мурза С. Манипуляция сознанием. Москва : Эксмо, 2005. С. 145.

12 Муазі Д. Геополітика емоцій. Як культури страху, приниження та надії змінюють світ / пер. з анл. О. Гординчук. Київ : Брайт Стар Паблішинг, 2018. С. 28.

13 Бауман 3. Индивидуализированное общество / Пер. с англ. под ред. В.Л. Иноземцева. Москва : Логос, 2005. С. 47. 
relations. Among such feelings and emotions an important place is occupied by fear, which is the subject of our research.

Fear is considered to be one of the strongest feelings and stimuli, which are aimed at the source of real or imagined danger that creates a need for security arising in a situation of threat to the biological or social existence of the individual ${ }^{14}$. D. Moysi claims in his research that fear is "an emotional reaction to a real or hypertrophied feeling of ever-closer danger. Fear evokes a protective reflex that manifests and reflects the individuality and vulnerability of a person, culture or civilization at some point". The researcher is convinced that fear acts not only as an indicator of emotions, but also makes it possible to construct multiple reality ${ }^{15}$.

At the core of almost all fear triggers is a sense of threat of harm physical or moral. It is very similar to how restricting physical activity can be an innate trigger for anger. The threat of physical pain is an innate trigger for fear, although, as P. Ekman affirms, at the time of pain, fear may not be felt at all. When we feel fear, we can do either absolutely everything or nothing, depending on the knowledge we have accumulated about what can protect us in the situation in which we find ourselves. According to the researcher, the behaviour of a person who feels fear focuses on two main actions - escape and attempt to hide ${ }^{16}$. When feeling fear and realizing that you are scared of something, it is quite difficult to feel any other emotion for a certain period of time, or to focus on someone else who is not the source of this fear. The mind and attention are concentrated on the danger. In a situation where there is a situational threat, the individual is focused on it until it is eliminated, although if at some point one realizes that nothing can be done about this danger - he or she begins to feel horror. The feeling of threat, as P. Ekman aptly observes, can completely take over our consciousness for a long time. Situational fear is able to concentrate our attention, acting as an indicator of mobilization of the individual to overcome the danger ${ }^{17}$.

There are two main types of fear: true (real) and illusory. As far as real fear is concerned, first of all we pay attention to the fact that it embodies the expression of the instinct of self-preservation, signalling us of danger, and forcing us under the influence of a real threat to choose to save our lives (escape, protection, attack, etc.). Moreover, this fear can also be exaggerated

${ }^{14}$ Герцберг Ф. Теория мотивации. URL: https://jkpersyblog.com/frederik-gercbergteoriya-motivacii/ (accessed 19.09.2017)

15 Муазі Д. Геополітика емоцій. Як культури страху, приниження та надії змінюють світ / Пер. $з$ англ. О. Гординчук. Київ : Брайт Стар паблішинг, 2018. С. 113.

16 Экман П. Психология эмоций. Я знаю, что ты чувствуешь. 2-е изд. / Пер. с англ. Санкт-Петербург : Питер, 2010. С. 92.

${ }^{17}$ Там само. С. 97. 
to some extent, which overestimates the danger. Yet, there is a kind of illusory or neurotic fear, which does not signal a real danger, but is constructed in the imagination by means of symbols or "virtual reality"

Obviously, fear can be manifested at the level of individual emotions or be a reflection of the emotional state of the collective or mass consciousness. Nevertheless, individual fears arise not only at the level of individual mental structure, they are largely internalized by individuals from the social environment. What unites them is the fact that they originate in society and normally have social consequences, regardless of whether the object of fear is a phenomenon of the political or non-political sphere. The collective level of emotions with the constant increase of real, predictable and constructed fears converts the individual emotion into an important element and factor of policy. In this sense, fear can have far-reaching political consequences: determine public policy, bring new groups to power and prevent others, make and repeal laws ${ }^{19}$. Fear can also contribute to the emergence of new values, ideologies, international principles. Namely, at the present stage, fear has a transformational potential to change norms, institutions, and, consequently, politics. Fear is transformed from an instrument of policy into a policy of fear, i.e. the policy based on fear, which in fear "finds inspiration and its own significance" 20 .

Politicians use fear to conceal the real motives for decision-making, as well as a powerful stimulus for the formation of public opinion. Causing irrational emotions, they mobilize citizens under the banner of populist ideas. The emotional response to fear as a political stimulus, to uncertainty, instability, and anxiety in social discourses and relations has led to a culture of fear that most researchers attribute to the increased extremism following the September 11, 2001 terrorist attacks in the United States of America. "Constant reference to a "war on terror" did accomplish one major objective: It stimulated the emergence of a culture of fear", stated Z. Brzezinski ${ }^{21}$. D. Moysi associates the culture of fear with the self-determination crisis of Western countries ("lack of confidence") in the globalized world and the loss of their hegemonic position. The culture of fear, as D. Moysi emphasizes, reduces the qualitative difference between democratic and non-democratic

${ }^{18}$ Кара-Мурза С. Манипуляция сознанием. Москва : Эксмо, 2005. С. 149.

19 Робин К. Страх. История политической идеи / Пер. с англ. А. Георгиева, М. Рудакова. Москва : Прогресс-традиция; Издательский дом «Территория будущего», 2007. С. 11.

${ }^{20}$ Robin C. Against the Politics of Fear. URL: https://www.jacobinmag.com/2016/ 12/against-politics-fear-trump-republicans-organizing-change/ (accessed 10.12.2020).

${ }^{21}$ Brzezinski Z. Terrorized by "War on Terror". Washington Post. 25.03.2007. URL: http://www.washingtonpost.com/wp-dyn/content/article/2007/03/23/AR2007032301613.html (accessed 07.12.2020). 
regimes. Fear pushes countries to violate their own moral principles, especially those that are based on strict adherence to the rule of law. When democracies propagate values that they no longer profess, they lose their moral support, and with it the power of their attractiveness ${ }^{22}$. It should be specified here that they are losing legitimacy.

The British sociologist F. Furedi considers the defining feature of the culture of fear to be "the belief that humanity is confronted by powerful destructive forces that threaten our everyday existence" ${ }^{23}$. Fear is not only a response to threats; it has become a worldview, a picture of the world formed in people's minds by politicians and the media. The gradual loss of connection between risks and everyday aspects of people's lives has created the culture of fear. Hence, the modern perception of risks and the strengthening of social fears are not related to personal experience, but to the constructed culture of fear.

The emotions of fear are consciously used to achieve political gain, such as the enhancement of authoritarian governance principles, the consolidation of society around the strategies and goals that are beneficial to elites, etc. "Fear obscures reason, intensifies emotions and makes it easier for demagogic politicians to mobilize the public on behalf of the policies they want to pursue", warned Z. Brzezinski ${ }^{24}$.

The beneficiaries of the culture of fear, in addition to politicians, are businesses, specifically large multinational campaigns, for which fear is an effective tool to increase sales; community activists, non-profit organizations that produce fears to obtain grants, donations to combat them; the media that increasingly exploit fear to gain their market share and simultaneously are a tool for other groups to construct and politicize threats. These actors, dramatizing the narratives and symbols of the problem through discourse, present them as a high priority, even though objectively they may not be.

Uncertainty, the growing influence of technology, the unlimited opportunity to demonstrate violence and armed conflicts online, the helplessness of institutions in regulating political narratives are all factors that exacerbate and manipulate the fears of the modern individual.

${ }^{22}$ Муазі Д. Геополітика емоцій. Як культури страху, приниження та надії змінюють світ / Пер. 3 англ. О. Гординчук. Київ : Брайт Стар паблішинг, 2018. C. 115 .

${ }^{23}$ Furedi F. Culture of Fear: Risk Taking and the Morality of Low Expectation. London, New York: Continuum, 2002. P. vii.

${ }^{24}$ Brzezinski Z. Terrorized by "War on Terror". Washington Post. 25.03.2007. URL: http://www.washingtonpost.com/wp-dyn/content/article/2007/03/23/AR2007032301613.html (accessed 07.12.2020). 


\section{Digitalization of the narrative of fear in political manipulation}

Perception of threats in the modern world can have various consequences - from mass emotional stress, panic, social unrest to mobilization and unification of society around overcoming danger, which is largely due to the way they are represented in discursive and narrative practices. The society's awareness of the threat is developed via the influence of a set of texts about it, i.e. discourse. It permits the political elite or other actors to manipulatively construct a hierarchy of threats that is advantageous to them. However, for the manipulation to deliver results and induce emotions of fear, confusion, to lead to a decrease in rational thinking, or even "disable" it, it is necessary that the proposed messages are at least partially superimposed on the inner feelings, knowledge of the individuals, their picture of the world. The mechanism that gives an opportunity to integrate external information influences into the individual's own experience is narrativization, for the reason that the discourse is based on narrative models.

Narratives (stories, narrations) have become an essential element of the information and political space of the postmodern era, in which knowledge acquires the characteristics of the principal productive force. The famous French philosopher Jean-François Lyotard considered new forms of knowledge and variants of truth, and traced the relationship between knowledge and power. Particularly, this refers to the effect through the distribution of knowledge and manipulation of discourses that express this knowledge ${ }^{25}$. In the work "The Postmodern Condition" Jean-François Lyotard focuses on narratives as the basic forms of "consumption" of knowledge - stories that characterize a certain type of discourse in various historical periods, in different structures, and form an empirical perception of oneself and the world. In other words, narratives are stories we tell ourselves and others about the world that we live in. Like myths, narratives legitimize institutions, socio-political practices, and legislation, though are more focused on the future ${ }^{26}$. As a representative of a certain culture, the individual learns its senses and meanings in the form of various stories that are retold by narrators. In the past these numerous "stories" were myths, the "foundation" of diverse religions, ideologies and related beliefs or metanarratives; master-narratives; grand narratives; etc. ${ }^{27}$. Metanarratives as a characteristic of modernism and a reflection of traditional ideologies

${ }^{25}$ Lyotard J.-F. The Postmodern Condition: A Report on Knowledge. Minneapolis, MN: University of Minnesota Press. 1984. P. 45.

${ }^{26}$ Лиотар Ж-Ф. Заметки на полях повествований. Комментарии. 1997. № 11. C. 215.

${ }^{27}$ Ожеван М.А. Глобальна війна стратегічних наративів: виклики та ризики для України. Стратегічні пріоритети. Серія: Політика. 2016. № 4. С. 32. 
imposed a certain set of ideological ideas on society. These ideas organized and controlled human consciousness and behaviour, were a form of violence and power.

Postmodernism, which is a consequence of the crisis of grand narratives, is characterized by the fragmentation, dispersion of great stories, the dominance of local stories that reflect mostly everyday human life (small stories). Postmodern narratives correspond, on the one hand, to the pluralism, complexity and even chaos of the modern world, and on the other hand - to the decentralized individual who is in constant search of oneself. In the postmodern condition, "the majority of people are narrators in comprehending their attitude to themselves", and the texts have much greater transmission potential, since they are easier to remember and retell than compact, consistent and coherent texts of judgments, as well as causation and incidence ones ${ }^{28}$. Yuval Harari proves that humanity thinks in narratives, not facts, and the simpler the story, the better ${ }^{29}$ (p. 19); life can also be perceived through a fictional story. From the point of view of psychological science, the free interpretation of the story is an opportunity to know oneself. Concurrently, there arise assembled, lacerated narratives, chaotic stories, cumulative tales, which allow for the use of "open concepts of narrative" as an intersubjective, intentional and axiological narration. In the information-saturated environment with competing or even conflicting discourses, the individual tends to rely on narrative as a way of understanding the world and giving substance to it.

Thus, narrative as a linguistic and psychological structure of the manifestation and organization of knowledge, senses creates an interpretive framework that the individual imposes on the reality, which is being conceived. Any narration "always requires interpretation (both by the author and the recipient), accordingly, narrative not only represents but also reproduces and re-reproduces reality in human perception, i.e. "creates reality", and at the same time as a narration it asserts its "independence" from this same "reality"; in other words, narrative equally "discovers and interprets the world, and conceals and distorts it" ${ }^{30}$. This means that a particular event and the story of it in one context can be presented as significant, priority, and in another as unessential. An example of such a story is the coverage of the Israeli invasion of Lebanon in the summer of 2006. Depending on whose reports appeared first, the impression was

${ }^{28}$ Музиль Р. Человек без свойств: роман в 2 кн. Кн. 1 / Пер. с нем. пер. С. Апта. Москва : Художественная литература, 1984. С. 729.

${ }^{29}$ Харарі Ю.Н. 21 урок для 21 століття / Пер. 3 англ. Київ : Book Chef, Форс, 2020. C. 19.

30 Ильин И.П. Постструктурализм. Деконструктивизм. Постмодернизм. Москва : Интрада, 1996. С. 217-218. 
formed of completely different "wars" and the reasons for their emergence, as well as the sources of aggression. A similar situation with opposite narratives is typical of the Azerbaijani-Armenian war in late 2020. According to D. Moysi, in the world where there is virtually no monopoly on the media, the events and conflicts are covered from diverse points of view $^{31}$.

Narrative, interpreting reality, changes it, creates new realities. The multiplicity of discourses and narrative schemes determines the situation where "reality is not given to us all by itself", but "speaks in many voices that interpret this reality" 32 . This explains the significant difference between the material world and the reality formed by narratives. As J. Brockmeier and R. Harré point out, "the material world is indeed complex and multifaceted, but each version captures only one aspect of the single physical universe" 33 . So, narrative cannot manifest the single and true reality; narrative contains facts and their interpretation; narrative can level, emphasize, or even exaggerate certain aspects or events that occur in physical (objective) reality, presenting them in different cultural, ideological, etc. contexts.

Thus, the interpretive and constructive possibilities of narrative give grounds to consider it as an effective tool of manipulative influence on the mass consciousness. Narrative technologies and practices of influence are also relevant for the spread of emotions of fear, for its manipulation. Their effectiveness is increasing in the digital age, in which unlimited and virtually uncontrolled information flows provide the individual with unlimited access to information, yet its oversaturation reduces everything to the "slipping" from one piece of news to another, and as a result to the superficial and uncritical perception of the content, does not allow for the penetration into socio-political problems. The progress of information leads to a decrease in public awareness ${ }^{34}$. Fakes, infoviruses, which are spread in various narratives, form a distorted perception of reality, evoke the necessary emotions of fear and existential danger.

Media narratives, or stories by means of the media, have a powerful impact on the mass consciousness and political behaviour. The peculiarity of

31 Муазі Д. Геополітика емоцій. Як культури страху, приниження та надії змінюють світ / Пер. $з$ англ. О. Гординчук. Київ : Брайт Стар паблішинг, 2018. С. 29.

${ }^{32}$ Афанасьєв O.I., Василенко I.Л. Функції наративу в науковому дискурсі. URL: https://www.sworld.com.ua/simpoz5/20.pdf (дата звернення: 10.12.2020).

33 Брокмейер Й., Харре Р. Нарратив: проблемы и обещания одной альтернативной парадигмы. Вопросы философии. 2000. № 3. С. 35.

${ }^{34}$ Monbiot G. The Need to Protect the Internet from «Astroturfing» Growsever More Urgent. URL: http://www.theguardian.com/environment/georgemonbiot/2011/feb/23/need-toprotect-internet-from-astroturfing (accessed 05.12.2020). 
the structure of media narratives is the ratio of objective facts and analytical conclusions, ready-made interpretations and embedded fakes. The most convincing are the interpretations that offer a relatively holistic picture of the world, but different from beliefs. Fakes, as an element of narrative, are just as difficult to refute since they are protected by its independence and selfsufficiency. In the media narrative there is a gap between reality and its linguistic and symbolic reflection.

Another type of narrative is viral, i.e. one which is able to spread itself. The notion of virality refers to the viral distribution of information by users of a product or service. The viral narrative is also an information product that is designed for a specific narrow audience. This is a message for the target audience, which is integrated into the story. Johan Berger identified six principles of virality: goods or ideas have a social currency (a desire to share something), are triggered, emotional, social, have practical value, and are wrapped in interesting stories ${ }^{35}$. The major task of the narrator is to determine the target audience of users who will distribute the story. The designers of viral narratives of fear, as ranked by M. Goodman, are: sovereign states, local hooligans, transnational organized criminal groups, foreign intelligence services, hacktivists, servicemen, cyber-troops, statefunded proxy fighters, amateur hackers, ordinary hackers, phreaks, carders, crackers, disgruntled insiders, industrial spies, etc. ${ }^{36} \mathrm{We}$ should add to this list numerous Internet bloggers, "experts" and other influencers. Theoretically, anyone can become the creator of a viral narrative. Moreover, it can be created accidentally by a user who does not have the skills to develop viral products. In most cases, viral narratives are based on emotionally controversial texts or videos, often with questionable content. By the way, negative narratives, which attract more attention and interest, and also mould emotions of fear, hatred, are much more likely to become viral than narratives with positive content.

Translators of discourses and narratives have traditionally been the media. Nation-states and their institutions created basic (large) narratives and controlled their distribution. However, the end of the past and the beginning of the XXI century are characterized by a completely new situation which was caused by the revolution in the information and communication sphere. The sudden development of Internet and digital technologies, e-government, social networks have notably transformed the information space. Within this space,

35 Бергер Й. Заразливий. Психологія вірусного маркетингу. Чому товари та ідеї стають популярним / Пер. 3 англ. Олени Замойської; 3-тє вид. Київ : Наш формат, 2017. С. 31.

${ }^{36}$ Гудмен М. Злочини майбутнього / Пер. з англ. Мазарчук І. Мишко Я. Харків : Фабула, 2019. С. 37. 
individuals can "communicate outside the traditional state hierarchies of intercommunications", nonetheless "social media platforms have generated a political reversal: a regression from centralized models of communication to the more chaotic network effects of the past ${ }^{37}$. The Internet implies not only computers connected to the global network, but also the powerful use of new media - the new media that are gradually becoming the primary source of information for citizens in the majority of countries, which is characterized by extraterritoriality, interactivity, unlimited user coverage, intensity of information production. Social media technologies have provided ordinary citizens with the opportunity to "become "authors", users who are also able to produce content" 38 .

Thus, the new media is a tool that remarkably enhances the effectiveness of traditional methods of communication and collective actions, an additional and fast channel of communication for their coordination. However, they also enable destructive actions that can be implemented only or more successfully by virtue of the Internet - hacking, cyber-terrorism, spread of propaganda, misinformation, information warfare. There is no doubt that the new media have been transformed into a tool for manipulation. What is more, this tool can be used by anyone. Global media companies, which own key social networks and messengers (Facebook, Twitter, Instagram, Telegram, Viber, etc.) and through which most stories are broadcast, are subject to internal rules and codes, and are virtually unaccountable to national governments. They act in their own interests to earn a profit, using artificial intelligence algorithms. Nation-states have lost control of the information space, which might threaten their sovereignty, legitimacy of governments, and their ability to respond to challenges and threats.

Social networks not only allow unlimited broadcasting of discourses and narratives, they also provide various agents with an opportunity to collect and analyse data of Internet users, create their psychological profiles and afford or sell the micro-targeting technologies to interested actors for use. An example that revealed this shadow side of the operation of digital technologies was the scandal with Cambridge Analytica and Facebook ${ }^{39}$. Cambridge Analytica collected user data (from 50 to 80 million), including American and British

${ }^{37}$ Патрикаракос Д. Війна у 140 знаках. Як соціальні медіа змінюють конфлікти у XXI столітті / Пер. 3 англ. І. Рудько. Київ : Yakaboo Publishind, 2019. С. 25.

${ }^{38}$ там само.

39 Confessore N. Cambridge Analytica and Facebook: The Scandal and the Fallout So Far. The New York Times. 04.04.2018. URL: https://www.nytimes.com/ 2018/04/04/us/politics/cambridge-analytica-scandal-fallout.html (accessed 11.12.2020); Rosenberg M., Confessore N., Cadwalladr C. How Trump Consultants Exploited the Facebook Data of Millions. The New York Times. 17.03.2017. URL: https:// www.nytimes.com/2018/03/17/us/politics/cambridge-analytica-trump-campaign.html (accessed 11.12.2020). 
voters, which could have affected Brexit results and the 2016 United States presidential election. Such manipulations not only afford an opportunity to identify and profile the emotions, feelings, needs, preferences of users, but also to generate texts for them that will reflect their expectations and fears. A powerful arsenal of software and analytical tools enhances the ability of digital media companies and advertisers to obtain valuable information, forecast, evaluate, classify behavioural, demographic, and psychographic personal data, practically transforming the user into a product.

In the current circumstances, digital technologies are gaining universal, global influence. Examples include the global spread of narratives stemming from the fears of climate change, poverty, military conflict, terrorism, uncontrolled migration, and gender or racial inequality.

A striking example of the spread of narratives that create uncertainty of the future and existential fear in individuals is the situation with the coronavirus pandemic. During the pandemic, which have affected the lives of all nations and peoples, the "post-pandemic" narrative that is based on the interpretation of the radical and global consequences of the pandemic - "the world will never return to pre-pandemic state", "global chaos", "economic crisis", "need to restrict human rights and freedoms", "failure of international institutions", "rise of China and crisis of the West" - is actively spread in both the scientific and media spheres. All these discursive structures, along with the justified fears caused by the coronavirus, form narratives by way of which any events or processes are interpreted at different levels - from individual to global, and most importantly the decisions and strategies proposed by national governments to ensure security under pandemic conditions are perceived. Emotions, in particular fears, which are moulded within this global narrative often lead to criticism (not always fair) of government actions, intussusception and support of populist anti-systemic political forces, they motivate citizens to mass protests, riots and other destructive actions.

The emotions of fear and uncertainty that they form reinforce the functioning and influence of discourses, which are grounded in conspiracy theories with opposite meanings - from claims that the "pandemic is fictional", is an occasion for "Masons" and "world government" to "solve the demographic problem", redistribute spheres of influence, "chip", "deprive of liberty" of the majority of humanity, etc. - to depictions of apocalyptic global scenarios, the collapse of the EU, the Schengen system or NATO, etc. We should agree with Georgii Pocheptsov that "fakes and conspiracy appeared to be the response of mass consciousness to the misunderstandings and fears of the new world that emerged with the coronavirus ${ }^{\prime 40}$ and which are actively spread in the format of viral narratives.

40 Почепцов Г.Г. Короновирус: как меняется наше сознание и будущее. Харьков : Фолио, 2020. С. 85. 
The pandemic has created an ideal environment for the informational infection of millions of people who spend much more time on social media during the quarantine period. As early as February 2020, the World Health Organization (WHO) announced a large-scale "infodemia"41. At the Munich Security Conference, Director-General of the World Health Organization Tedros Ghebreyesus said: "Fake news spreads faster and more easily than this virus, and is therefore just as dangerous". Dissemination of contradictory or obviously false information about the origin of the virus, methods of protection and treatment, strategies to respond to the pandemic threat, etc. deepens the state of uncertainty, destroys social trust, solidarity and cooperation, which are important for overcoming the coronavirus and its consequences both within individual states and at the interstate level.

Certain countries are trying to take advantage of the pandemic crisis and the increased contamination of people with fakes through social networks in their claims to global leadership. This primarily refers to the information policy, but de facto the information war of China and the Russian Federation with the Western powers. These countries are spreading innumerable fake reports on the coronavirus pandemic for EU and US users. These reports are intended to develop fears that the democratic governments are unable to cope with the viral infection and they promote the idea that only authoritarian regimes can quickly mobilize society to combat any threat. It should be noted that such authoritarian narratives, actively disseminated by China and the Russian Federation, find fertile ground in the democracies against the background of daily reports of a steady increase in the incidence of coronavirus victims. Fear of the coronavirus infection, dissatisfaction with the democratic strategies to overcome it, are also used by China to clean up its reputation and mitigate the accusations of silencing the pandemic, ignoring its scientists' warnings of the new coronavirus, censoring information about the outbreak, which led to the wide spread of COVID-19 and the transformation of the epidemic into the pandemic. China, applying the Communist Party's giant propaganda machine, is successfully shaping the image of the "global leader in health care that saves the world from an unexpected outbreak of a dangerous viral infection" in the world and social media. This is also facilitated by the requirements to "film" the transfer of humanitarian aid. These images or video clips often show "grateful" leaders of European countries who sometimes kiss the Chinese flag. In fact, the assistance provided by China was not always assistance in the literal sense of the word, but was in part or in full an export supply of medical products and

41 Ghebreyesus T. Speech at the Munich Security Conference. URL: https://www.who.int/director-general/speeches/detail/munich-security-conference (accessed 11.12.2020). 
ventilators, although it was presented in the media as "humanitarian aid". It is noteworthy that democratic governments proved to be more vulnerable to infodemia since, unlike authoritarian states, they do not control information flows. Authoritarian China and Russia, other international players by way of the spread of fakes and alarmist narratives are trying to increase the effect of the coronavirus, cause panic and sow doubts about the effectiveness and legitimacy of democratic governments, weaken their position in the international arena.

To sum up, the translators of the "post-pandemic" narrative manage to form a viral brand of fear and convert the average user into a mass consumer and a tool for distribution in networks.

\section{CONCLUSIONS}

In conclusion, it should be noted that the emotional sphere of contemporary societies is an important factor in their development and political transformation. Among the elements of the emotional sphere of society an important place is held by fear - a reaction to a threat (real or imaginary), which can have a significant impact on mass political behaviour and socio-political relations. The current state of mass consciousness is characterized by the intensity of the emotions of fear and its active and effective application in manipulative political practices. Although fear is a predominantly instinctive reaction, manipulative technologies are able to steer it in the right direction, turning it into a technology of influence. Fear as a policy and culture can be a factor in the consolidation of society, the motivation to overcome social threats. However, fear as a rapid and often irrational reaction, due to the feelings of insecurity and loss of identity, can cause mass panic, social unrest and as a consequence - destruction of the institutional foundations of society, delegitimization of political governance. Mass emotional stresses and fears contribute to the authoritarianization of socio-political life, the accession to power of incompetent populist politicians and anti-system parties with promises to rapidly rid citizens (voters) of threats and dangers, which cannot be fulfilled.

The opportunity to construct mass fears and emotional states by means of discourse and narrative transforms fear into the foundation of modern politics, shapes the culture of fear based on the loss of connection between objective risks and personal experience as well as people's daily lives. Discourse and narrative are both the forms of fear representation, the way to interpret reality (risks, dangers) and the creation of a new reality. The interpretive and constructive potential of the narrative, and the narrative of fear in particular, gives grounds to consider it an effective means of political manipulation. The manipulative effect of the narrative is also enhanced by the ability to embed fakes, infoviruses. 
The efficacy of the fear narrative is multiplied through the widespread use of information and digital technologies, social networks and new media. These are primarily media narratives or narratives by means of the media and viral narratives that are characterized by the ability to spread virally.

In the current circumstances, narratives and embedded into them fakes, conspiracy theories are asserting their global character. Examples of such global narratives include the considered "pandemic" and "post-pandemic narratives", their application by politicians and national governments to realize the international ambitions. The described tendencies can provide background for transforming the "post-pandemic narrative" into a viral brand of fear.

\section{SUMMARY}

Peculiarities of discursivization and narrativization of fear in political practices of manipulation, their digital representation are analysed. The manipulative potential of fear as a reaction of the modern individual and society to growing threats and uncertainty in the development of sociopolitical processes is substantiated. The essence and nature of the culture of fear as a modern perception of risks, constructed discursively and in the media, are analysed. This transforms fear from an instrument of policy into a policy of fear. Representative, interpretive and constructive possibilities of narrative as effective means of manipulative influence on the mass consciousness are clarified. Characteristics and principles of functioning of media and viral narratives are determined. The dynamics of the emergence of digital narratives in the context of the pandemic world is traced.

\section{REFERENCES}

1. Афанасьєв О.І., Василенко І.Л. Функції наративу в науковому дискурсі. URL: https://www.sworld.com.ua/simpoz5/20.pdf (accessed 10.12.2020).

2. Бауман 3. Индивидуализированное общество / Пер. с англ. под ред. В.Л. Иноземцева. Москва : Логос, 2005. 390 с.

3. Бергер Й. Заразливий. Психологія вірусного маркетингу. Чому товари та ідеї стають популярним / Пер. з англ. О. Замойської; 3-тє вид. Київ : Наш формат, 2017. 196 с.

4. Брокмейер Й., Харре Р. Нарратив: проблемы и обещания одной альтернативной парадигмы. Вопросы философии. 2000. № 3. С. 29-42.

5. Водак Р. Политика страха. Что значит дискурс правых популистов? / Кочергина Е.Н., Гритчина В.В. пер. с англ. Харьков : Изд-во «Гуманитарный центр», 2018. 404 с.

6. Гарднер Д. Страх. Почему мы неправильно оцениваем риски, живя в самое безопасное время в истории / Пер. с англ. Ю. Константинова. Москва : ООО «Манн, Иванов и Фербер», 2019. 320 с. 
7. Герцберг Ф. Теория мотивации. URL: https://jkpersyblog.com/ frederik-gercberg-teoriya-motivacii/ (accessed 19. 09. 2017)

8. Гудмен М. Злочини майбутнього / Пер. 3 англ. Мазарчук I., Мишко Я. Харків : Фабула, 2019. 592 с.

9. Давыдов В.В. Психология деятельности как основа формирования способности и готовности к практической деятельности. Москва : Наука, 1997. 231 с.

10. Доценко Е.Л. Психология манипуляции: феномены, механизмы и защита. Москва : ЧеРо, Издательство МГУ, 1997. 344 с.

11. Ильин И.П. Постструктурализм. Деконструктивизм. Постмодернизм. Москва : Интрада, 1996. 256 с.

12. Кара-Мурза С. Манипуляция сознанием. Москва : Эксмо, 2005. $832 \mathrm{c}$.

13. Лиотар Ж-Ф. Заметки на полях повествований. Комментарии. 1997. № 11. С. 215-218.

14. Липпман У. Общественное мнение / Пер. с англ. Москва : Институт Фонда «Общественное мнение», 2004. 382 с.

15. Муазі Д. Геополітика емоцій. Як культури страху, приниження та надії змінюють світ / Пер. з англ. О. Гординчук. Київ : Брайт Стар паблішинг, 2018. 184 с.

16. Музиль Р. Человек без свойств: роман в 2 кн. Кн. 1 / Пер. с нем. С. Апта. Москва : Художественная литература, 1984. 751 с.

17. Ожеван М.А. Глобальна війна стратегічних наративів: виклики та ризики для України. Стратегічні пріоритети. Серія: Політика. 2016. № 4. C. 30-40.

18. Патрикаракос Д. Війна у 140 знаках. Як соціальні медіа змінюють конфлікти у XXI столітті / Пер. 3 англ. І. Рудько. Київ : Yakaboo Publishind, 2019. 352 c.

19. Почепцов Г. Г. Короновирус: как меняется наше сознание и будущее. Харьков : Фолио, 2020. 256 с.

20. Робин К. Страх. История политической идеи / Пер. с англ. А. Георгиева, М. Рудакова. Москва : Прогресс-традиция; Издательский дом «Территория будущего», 2007. 368 с.

21. Харарі Ю.Н. 21 урок для 21 століття / Пер. 3 англ. Київ : Book Chef, Форс, 2020. 416 c.

22. Экман П. Психология эмоций. Я знаю, что ты чувствуешь. 2-е изд. / Пер. с англ. Санкт-Петербург : Питер, 2010. 334 с.

23. Brzezinski Z. Terrorized by «War on Terror». Washington Post. 25.03.2007. URL: http://www.washingtonpost.com/wp-dyn/content/article/ 2007/03/23/ AR2007032301613.html (accessed 07.12.2020).

24. Confessore N. Cambridge Analytica and Facebook: The Scandal and the Fallout So Far. The New York Times. 04.04.2018. URL: 
https://www.nytimes.com/2018/04/04/us/politics/cambridge-analytica-scan dalfallout.html (accessed 11.12.2020).

25. Furedi F. Culture of Fear: Risk Taking and the Morality of Low Expectation. London, New York: Continuum, 2002. 205 p.

26. Ghebreyesus T. Speech at the Munich Security Conference. URL: https://www.who.int/director-general/speeches/detail/munich-security-conference (accessed 11.12.2020).

27. Lyotard J.-F. The Postmodern Condition: A Report on Knowledge. Minneapolis, MN: University of Minnesota Press. 1984. 144 p.

28. Monbiot G. The Need to Protect the Internet from «Astroturfing» Growsever More Urgent. URL: http://www.theguardian.com/environment/ georgemonbiot/2011/feb/23/need-to-protect-internet-from-astroturfing (accessed 05.12.2020).

29. Robin C. Against the Politics of Fear. URL: https://www. jacobinmag.com/2016/12/against-politics-fear-trump-republicans-organizingchange/ (accessed 10.12.2020).

30. Rosenberg M., Confessore N., Cadwalladr C. How Trump Consultants Exploited the Facebook Data of Millions. The New York Times. 17.03.2017. URL: https://www.nytimes.com/2018/03/17/us/politics/cambridge-analytica-trump-campaign.html (accessed 11.12.2020).

Information about the authors: Uhryn L. Ya., $\mathrm{PhD}$ of Political Science, Associate Professor at the Department of Theory and History of Political Science Ivan Franko National University of Lviv 1, Universytetska str., Lviv, 79000, Ukraine

Sviderska O. I., $\mathrm{PhD}$ of Political Science, Assistant Professor at the Department of Theoretical and Practical Psychology

Lviv Polytechnic National University 12, S. Bandera Str., Lviv, 79013, Ukraine

Bula S. P., $\mathrm{PhD}$ of Political Science, Associate Professor at the Department of Political Science Ivan Franko National University of Lviv 1, Universytetska str., Lviv, 79000, Ukraine 